\title{
Killing Oneself, Killing the Father \\ : On Deleuze's Suicide in Comparison with Blanchot's Notion of Death
}

On the fourth of November in 1995, after long suffering from a respiratory disease, Deleuze killed himself by throwing himself out the window of his apartment. Since his death, many articles on his suicide have been published. Among them are several attempts to interpret his death philosophically. Some apply Diogenes Laertius' method to Deleuze's death, a method invoked in The Logic of Sense: "to find vital Aphorisms which would also be Anecdotes of thought" in the gesture of philosophers ${ }^{1}$. In one essay, the author A. de G. compares Deleuze's suicide to Empedocles' throwing himself in the Aetna, a philosophical gesture Deleuze himself treats as such a "vital Aphorism" and an "Anecdote of thought"2.

If Deleuze's death is an aphorism, it should be ruminated on, as Nietzsche says. In the course of such a rumination, an aphorism calls for diverse interpretations. André Pierre Colombat, in his "November 4, 1995: Deleuze's death as an event", finds in Deleuze's death such an aphorism and anecdote, but interprets it differently. Although Deleuze honors Empedocles, he regards him as the second of "three images of philosophers", after Plato and before the Stoics or the Cynics ${ }^{3}$. Hence Colombat claims that Deleuze's death should be considered in the wake of the final grouping of philosophers, more in relation to the incorporeal surface of sense or event in which the Stoics or the Cynics moved than the corporeal depth of Nature Empedocles explored or the heights of Ideas toward which Plato strove.

Colombat interprets Deleuze's death in connection with Blanchot's notion of the second death, which Deleuze himself had previously appropriated. Blanchot distinguishes two kinds of death. While the first death is the death which actually happens, dated and situated within history, the second death is the pure form-not only of the first death but also of the event in general, as "the sense of what happens". In its pure form, this second 
death never arrives. Yet, remaining unrealized, it expresses the power of life to create something continuously new. Colombat insists that Deleuze's suicide is an act of dissolving himself into the second death, in that it is "similar to Nietzschean throw of the dice" through which "the individual rejoins the 'empty shape of time", the pure form of the event. It is "a very positive, concrete and philosophical act of assertion" of the power of life 4 . It is in this context that Colombat finds in Deleuze's suicide a "vital Aphorism" and an "Anecdote of thought".

But there are a few problems with Colombat's interpretation. One of them concerns the necessity of Deleuze's suicide. If the second death is the pure form of the event, it is not only suicide, but literally everything that happens, including natural or accidental death, that can assert the power of life. Thus the necessity of committing suicide becomes unclear. Colombat eschews this question, saying that "death always comes from the outside", and that "the idea that death comes from inside of us is a life degrading [sic] idea, created by the priest, the Hegelian philosopher and the psychiatrist" ${ }^{5}$. However the act of giving oneself death is conclusively distinct from the attitude of just waiting for death. An act or attitude can be a "vital Aphorism" and an "Anecdote of thought" only insofar as that very action has the unique necessity that only it can have, since it is rooted in the thought of one who commits that act or takes that attitude. Such a necessity should be sought in Deleuze's suicide, without reducing this necessity to mere interiority.

Another problem with Colombat's interpretation concerns the difference between Blanchot and Deleuze. For Blanchot, the first death which happens and the second death which never happens cannot coincide. If Deleuze's suicide is nothing but the first death, and can nevertheless be regarded as an act of rejoining the second death, a different conception of the two kinds of death must be supposed. So, before relating Deleuze's suicide to Blanchot's second death, we should ask how Deleuze modified Blanchot's conception of death into his own. The answer will help to illuminate the necessity of 
Deleuze's suicide.

\section{Two Deaths and Suicide in Blanchot}

I will begin by considering Blanchot's framework as Deleuze adapts it. According to Blanchot, suicide cannot rejoin the second death. This is the consequence of his conception of the two deaths as being utterly separated from each other, one imprisoning a dying person in his or her identity and the other nullifying this identity.

The first death which happens in history is called 'I die'. It is the disappearance of the subject with its proper identity, concomitant with the loss of the life of a person. Personal identity, rather than preexisting this death, is crucially fixed by it. With the disappearance of a specific identity, it becomes impossible for the individual who died to act, or interact with their environment. Through this lack of action, the kind of person who one was can be clearly identified. Whether we wish to or not, we have to die this first death when we actually die.

In contrast, the second death is the anonymous death, the 'it dies', much like the mere perishing of living things other than human beings. Since everyone or everything living dies indiscriminately, the pure form of death shows itself in such anonymity. But the second death is not the simple loss of life, even in the case of a nameless creature. Strictly speaking, death never arrives to one who dies, because, when one dies, the one to whom this death should arrive also disappears. In Derrida's words, "there is only ... the instant of my death always in abeyance"6. Rather than arriving at a certain point of time, death casts its shadow on everything in every moment, in the shape of the changes everything undergoes in moving towards death. This is death in its genuine form, the second death as "the infinite patience of that which is never accomplished once and for all" 7 . Then, if what happens is some change of everything, the pure form of the event is equivalent to the pure 
form of death-the death that never happens. That is why the second death is equated with the pure form of the event, the formless shape of transformation, inscribed in all changes.

As such, the second death, far from confirming the proper identity of each creature, displays the lack of such identity and the ceaseless fluctuation of everything. Since this fluctuation manifests the vitality of a living thing, the second death is also the form of the power of life. It is the death "in life's intimacy and profundity" ${ }^{2}$ "the incessant imminence whereby life lasts, desiring" 9 . Because of this imminence of the second death in life, Blanchot's insistence on death is essentially an affirmation of life.

Insofar as the second death marks every aspect of life, I as the subject cannot keep its identity intact. The unity of the I has been broken up, since, because of the imminence of the second death in life, all living things are exposed to continuous changes which not only lead to the first death but also themselves epitomize the second death. The second death, intrinsic to the I, takes the shape of the fracture of the self, split into 'I think' and 'I am'. When Descartes concluded 'I am' directly from 'I think', he took the unity of these two selves as self-evident. But Kant pointed out that there is a fracture between them. In order for them to be united, there must be the mode in which 'I am' is determinable by 'I think', and it is "a given a priori form, namely, time, which is sensible and belongs to the receptivity of the determinable"10. This is the pure form of time, experienced intuitively through a minimal difference.

The form of time which splits the self is also the form of the continuous change to which 'I am' is exposed. What intrudes into the self through this time lag, in order to bring about this continuous change, is the force of the Outside, which is known only as the unknown, the outside of thought. Any activity of life, or even the first death, as a part of such a change, comes from the Outside. The second death is the form of the receipt of the force of the Outside. As such, it shows, beyond and beneath the simple dichotomy between 
the superficial activity and the superficial passivity of the I, a radical passivity correlative with this force of the Outside11. The fracture between 'I think' and 'I am' denotes that this force has been affecting the self. So I as the subject am not confined within mere interiority, but am always open to the Outside, whether in life or in death in the first sense.

Thus, in epitomizing the second death, there is no privileging of the first death, or of suicide, since both are merely specific activities of life among many others. Indeed, Blanchot denounces suicide as an arrogant act, based on illusion and destined to failure. "Suicide's shortcut necessarily fails death, by transforming 'illusorily' the passivity of that which cannot take place because it has always already done so, into an active possibility" 12 . One who commits suicide, imagining that one can give oneself the death which can, supposedly, merely be given from the Outside, forcefully distorts the second death into the first death. By doing so, one believes that one can attain the supreme power to control one's life and death. This, however, is nothing but an illusion. In fact, one is merely thrown into the worst powerlessness of being killed peremptorily. "One cannot 'plan' to kill oneself'13, because death can never be at my disposal. If suicide could make sense, it would be only to the extent that it could disclose such an ineluctable failure of the project. In spite of his insistence on death, Blanchot actually tries "to avert us from suicide, by showing that it is no solution"14. By extracting the second death as the pure form not only of the first death but also of the event itself, he turns death against death, and protests against suicide, in the name of an affirmation of the life liberated from life itself degraded by the banality of a mundane daily routine or distorted by the audacity of a narcissistic dreamer.

\section{Deleuze in Contrast with Blanchot}

In Deleuze, death is also one with life liberated from life. For him, death is "an 
internal power which frees the individuating elements from the form of the I or the matter of the self in which they are imprisoned" 15 , rather than a return to the inanimate. Similarly to Blanchot, Deleuze's affirmation of life is in intimate relation with the affirmation of death.

Yet their positions are not exactly the same. In The Logic of Sense, where their contrast is very clear, Deleuze comments on Blanchot's view on suicide: "When Blanchot considers suicide as the will to make the two faces of death coincide, to prolong impersonal death by means of the most personal act, he clearly shows the inevitability of this connection or of this temptation to join them together. But he also tries to define the illusion. In fact, there is an entire difference of nature between what is joined together and what is tightly prolonged. But the problem is not here. For whom does this difference in nature subsist if not for the abstract thinker? And how could this thinker, with respect to this problem, not be ridiculous?"16 The abstract and ridiculous thinker appears to be a pointed description of Blanchot. In Deleuze's reading, Blanchot thinks that a belief that suicide can make the junction between the two deaths is an illusion, because of their naturally unbridgeable difference. However, such a difference subsists merely at an abstract level. If Deleuze criticizes Blanchot for indulging in such abstraction, it is probable that Deleuze expands the idea Blanchot abandons, the inevitability of the interconnection between the two deaths, although Deleuze only implicitly suggests this direction of thought.

In a general perspective, the point at issue between these two thinkers is whether the event as the sense of what happens can really be caught unless it is incarnated. For Deleuze, "the eternal truth of the event is grasped only if the event is also inscribed in the flesh"17, that is, the event cannot be gotten at without its incarnation. Giving the examples of Bousquet, Fitzgerald, Lowry and Artaud, Deleuze insists that they all wrote throughout the process of breaking down, whether wounded, alcoholic, or schizophrenic. "Each one 
risked something, went as far as possible in this risk, and drew from it an unprescriptible right. What is left for the abstract thinker once he has given advice of wisdom and distinction?"18 While all these writers faced what happened to them, extracted its sense, and expressed it in their works, the abstract thinker sticks to the separation between incorporeal senses and corporeal incidents, wants to get the former without the latter and tries "not to incarnate it [the incorporeal crack] in the depth of the body"19. That is why Deleuze criticizes Blanchot and calls him "the abstract thinker". Behind this criticism lies Deleuze's belief in the inseparability of the event and its incarnation.

Blanchot conceives the radical passivity of the second death as infinite patience with the incessant imminence of what never comes, has already come or remains to come. It is this conception that leads him to separate the event from its incarnation. However Deleuze, in his belief in their inseparability, seems to conceive this passivity as not merely correlative with but fused with the radical activity of what actually comes, the activity which is beyond and beneath the dichotomy of human activity and human passivity, but which nevertheless cannot but incarnate itself in them.

In terms of death, this belief does not immediately result in the biunivocal relationship between the two deaths, for the second death is not only the pure form of the first death but also that of all events, since Deleuze admits that "[e]very event is like death" 20 . Nevertheless, it is undeniable that he assumes an inextricable connection between the two deaths. In effect, as examples of incidents from which the events in their pure forms are extracted, Deleuze cites violence, oppression, tyranny, plague, war, wound and death ${ }^{21}$. They all are disastrous, and death is not excluded. If these incidents, which literally bring about the fracture of the self and are close or equal to the first death, are quite suitable for the extraction of the second death, it follows that the first death has a special familiarity with the second death. Certainly it is not the only way of revealing the pure form of the event, but one of many and yet an incomparable way that is the limit 
towards which all the others tend. In the end, Deleuze's claim that the event and its incarnation are inseparable is relevant to the two deaths. He alludes to the possibility of the joining of the two deaths in suicide, and leaves room for the possibility that the act of killing oneself can lead to the life liberated from life. For a philosopher of life, it is strange that death looms so large. The overlap of his suicide with that of Empedocles comes to the fore again. It is significant that Deleuze in Difference and Repetition invokes the image of the act of "throw[ing] oneself into the volcano" in Empedocles' manner, in order to render the pure form of time ${ }^{22}$. This invocation itself stands for the junction of the two deaths, based on the inseparability between what happens in the depth and its sense on the surface.

But, this is far from enough to explain the necessity of suicide. Rather, in reference to Deleuze's statements, the necessity of avoiding suicide looks predominant. Talking of "quite various ways in which the junction of the two [aspects of death] may be brought about", he cites "suicide, madness, the use of drugs or alcohol", and says: "Perhaps the last two means are the most perfect, because of the time they take, instead of bringing the two lines together in a fatal point" 23 . Here, rather than carrying out this junction decisively, as in suicide or madness, he argues for prolonging its process, suspending the end and making one's life last long, such as through the use of drugs or alcohol. Although he suggests the possibility of the junction of the two deaths in suicide, he does not seem to pursue this possibility so far as to turn it into a necessity. Two issues prevent him from doing so. One is general, concerning the act of achieving something at a fatal point. The other is particular to the act of killing oneself. Yet we can discern in his thought several lines of arguments which can allow us to surmount these difficulties. Examining what they are and how to surmount them will make clear Deleuze's unique position on suicide, which will explicate the necessity of his own suicide. 


\section{The Problem of 'Once And for All'}

First, in a general perspective, the act which accomplishes something and arrives at 'a fatal point' is problematic in itself. Here again, Deleuze's conversation with Blanchot guides him towards the elaboration of an original solution to this problem.

Blanchot discusses this problem in the course of his critique of Hegel's notion of death. Hegel errs when he claims that "only the fact of confronting death—not merely of facing it or of exposing oneself to its danger (this is the distinguishing feature of heroic courage), but of entering into its space, of undergoing it as infinite death, and also as sheer death, 'natural death'-could found sovereignty and mastery" ${ }^{24}$. Hegel believes that, through one's death, by facing and enduring this last and gravest incident just one time, one can complete oneself and gain the sovereign mastery not only over oneself but also over death. For Blanchot, such a suggestion is pure arrogance, similar to that which he finds in suicide. This arrogance, the self-confidence of the subject in its completion, is indissociable from the assumption of the fatal point of 'once and for all.' This assumption culminates in the Hegelian idea of the final goal of all that happens, at the end of the dialectical movement in history. Hegel thinks that, at this ultimate moment, the absolute Spirit of God incarnates itself in the subject and the subject attains its perfection. On a smaller scale, this applies to each accomplishment of any kind, which has its own history towards the goal. Any accomplishment embodies God's spirit to some extent, more or less; and this embodiment ensures the completion of the agent of this accomplishment. Therefore Hegel praises heroic and courageous death. Even suicide is its variant, insofar as it is an act of achieving something very difficult in confronting death. The basis of Blanchot's critique of Hegel's notion of death is a critique of the assumption of the 'once and for all,' an assumption which presupposes a complicity between the subject and God, in the way that God as the perfect One manifests Himself in the self-realization of the 
unified subject and guarantees its professed completeness ${ }^{25}$.

In Difference and Repetition, Deleuze also criticizes the idea of the 'once and for all', with regard to Kierkegaard and Péguy. Deleuze writes that, in these writers, "faith invites us to rediscover once and for all God and the self in a common resurrection" 26 . Although these writers once decry the vanity of the subject, they redeem its honor by the grace of God at the last moment. What is at issue here is not faith itself but rather "the betrothal of a self rediscovered and a god [sic] rediscovered" 27 established 'once and for all' in faith. On this point, Deleuze's position seems consistent with that of Blanchot.

Yet, surely there remains a dissonance between them. Deleuze does not always use the phrase 'once and for all' negatively, but also uses it positively, in relation to the fracture of the self. In his concept of the third synthesis of time, Deleuze refers to the fracture Kant discovered in Descartes, and equates it with the pure form of time, in the same manner as Blanchot. But, and here he differs from Blanchot, Deleuze connects this pure form of time to a specific image of an act or event. This connection reflects his idea of the fusion of radical passivity and radical activity, which is irreducible to human acts, but which nevertheless is somehow participated in by all that happens including these $\operatorname{acts}^{28}$.

Besides, this connection implies a positive aspect of the act which is far from being the means of self-realization. In this aspect, 'once and for all' appears in a different guise. By taking place, an act or event delineates its before and after. In the before as the past, the act or event has not taken place, and poses itself as too big for the one who faces it. In the after as the future, the act or event has already taken place. In the present between the past and the future, at the moment in time when the act or event takes place, a moment called the 'caesura', one becomes equal to the act or event enough to face it. This time of metamorphosis fractures the self and orders the before and the after of the act or event, corresponding to the divided parts of the self. Deleuze describes this situation: "It is the caesura, along with the before and after which it ordains once and for all, that 
constitutes the fracture in the I" 29 . He accepts 'once and for all', in reference to such ordering of time by the caesura which constitutes the fracture of the self. Since the identity of the self is guaranteed by the unity of God, the fractured I connotes the death of God. In this sense, Deleuze affirms the 'once and for all', insofar as it confirms "a different and more mortuary betrothal between the dead God and the dissolved self' 30 , in other words, insofar as it is said of the act of killing the subject and God as its guarantor.

Deleuze's conditional affirmation is in stark contrast to Blanchot's utter denial. “'God is dead', ... does not signify that humanity has once and for all gone beyond its fundamental moment" 31 . If Blanchot denies the 'once and for all' of the act of killing God, it is because he thinks that this "sacrificial act is complicit with God Himself" 32 . Any act of accomplishment, even when it brings the death of God, reconstitutes another form of the absolute, the subject who kills God, in His place. More exactly, such an act resurrects God in another guise. Even the act of killing the subject organizes another subject as the agent of this act. That is why Blanchot conceives of death in relation to radical passivity, "the infinite patience of that which is never accomplished once and for all”, which continues to arrive and never arrives-as that which has already come and is always to come. The companion to this patience is the imminence of the infinite movement of the Outside, the neutral which escapes from all determination, neither bound up in immanence nor transcendence. In the correlation of imminence and patience is "the confrontation of God who disappears and of the human who is responsible for this disappearance" 33 , God and human in conjugal deaths, both executed and suspended at once ${ }^{34}$. As such, death does not allow for any accomplishment which privileges itself.

In contrast, if Deleuze affirms 'once and for all' of the act of killing God and the subject, it is because he thinks that this act rejects absolutization and avoids their resurrection. For, this act, by eliminating the guarantor of its accomplishment, succeeds in never accomplishing itself, and prevents it from becoming absolute. So it alienates the 
subject from its completion. When God and the subject, the guarantor of the accomplishment of the act and its guaranteed agent, are thus removed, there is no privileged act achieved at some fatal point. Every act or event is as valuable as it is singular, at any point that it takes place. The act of killing God and the subject, after taking place, joins such acts or events. "The 'once and for all'...is there only for the 'every time"'35. Because of the fusion of radical activity and radical passivity in all that happens, any act constitutes the fracture of the self. So every act is in essence the act of killing God and the subject, to a greater or lesser extent. This contrasts with the positions of both Hegel and Blanchot: the former sees in every act of accomplishment the embodiment of God and the completion of the subject, and the latter, in opposition to the former, refuses any such act as resuscitating God and the subject.

The contrast between Deleuze and Blanchot comes from their differing conceptions of the Outside. Deleuze's high regard for the act is closely connected with his advocacy of immanence. For him, pure immanence is not immanent to something, but "immanent only to itself and consequently captures everything" 36 . If all things come from and return to the Outside, immanence is the alias of the Outside. It is this movement of coming and going that defines the fusion of radical passivity and radical activity in all that happens. This infinite movement of the Outside, rather than remaining in imminence and patience eschewing the present, incessantly actualizes itself in the present, however without reducing the Outside, the pure virtuality of the past and the future, to any actualization ${ }^{37}$. The repetition of the difference in such movement, blocking the emergence of transcendence, composes the plane of immanence. Hence every act or event is affirmed, as a part of this movement which accomplishes itself 'every time' 'once and for all' as never accomplished. From the viewpoint of such an act or event in general, even the act of suicide, which brings the two deaths together in 'a fatal point', can be allowed. For the equation of the Outside and immanence enables any act or event to achieve its own de- 
privileging, keeping it from embodying God and completing the subject.

\section{The Problem of Giving Oneself Death}

From a particular perspective, the specific act of suicide-the act which goes towards death-has its own problem. Even though the act in general is opened to the infinite movement of immanence, it is still uncertain whether the specific act of suicide can keep itself that open. The first death, which this act results in, amounts to confining the one who dies within a subjective identity, which precludes him or her from the force of the Outside. The fixation of this identity undoes a "mortuary betrothal between the dead God and the dissolved self' 38 , emerging in the act. The restitution of the self enabled by this fixation implies the restitution of the authority of its guarantor, in order to reestablish "the betrothal of a self rediscovered and a god rediscovered"39. However, even if this restitution is the inevitable result of the act of suicide, this act in its process has the ability to resist this result. Besides, in Deleuze's suicide, the first death turns against itself to break through the confinement in the self.

In Negotiations, Deleuze sees certain positivity in the process of suicide. This positivity comes from what he calls subjectivation. "Subjectivation, that's to say the operation which consists in folding the line of the outside, mustn't be seen as just a way of protecting oneself, taking shelter. On the contrary, it's the only way of confronting the line, riding it: you may be heading for death, suicide, but... suicide then becomes an art which costs the whole life" 40 . Distinguished from the subject by its closed interiority, subjectivation is an operation of folding the outside into the inside, thereby enabling an interchange between them, towards the creation of new modes of existence. Deleuze affirms suicide, insofar as it is an art of subjectivation.

Since the second death is the form of the receipt of the force of the Outside, the act 
that reveals this form in the shape of the fracture of the self is an operation of folding. Suicide can become subjectivation in such a sense, because it constitutes this fracture not only as an act in general, but also as the particular act of killing oneself. Blanchot argues that the one who kills oneself in order to get the supreme power to control one's life and death falls into the worst powerlessness of being killed peremptorily. In this collapse, the gap between the active self and the passive self yawns. This is the same kind of fracture as that between 'I think' and 'I am', and that which gets to the full extent of what one can experience, between the agent of the supreme power and the victim of the worst powerlessness. Certainly there is no need for suicide, merely for the sake of attaining the second death, inscribed in every change of everything. But suicide has a specificity that maximizes the fracture of the self and reveals the second death most conspicuously in the midst of the first death. Even if unintentionally, Blanchot has depicted this specificity, which is also implied in Deleuze's claims about the inseparability of the two deaths.

The fracture that is maximized in suicide enables extraordinary subjectivation. The fracture of the self which the act constitutes does not split the act in itself. Rather, by its "secret coherence which excludes that of the self" 41 , the act traverses this fracture without filling it, in order to trace the plane of immanence. Such coherence attests to the fact that the destruction of the established mode of existence can prepare the way for the creation of new modes of existence which incorporate the force of the Outside otherwise, although they are merely glimpsed in their potentials. So the act which in essence demolishes the subject can be subjectivation. In suicide, the act of killing oneself, traversing the largest fracture and connecting the furthest terms, folds the force of the Outside and expresses the power of life to the utmost, tracing the broadest plane of immanence. Here subjectivation gains the most intensive potential of new modes of existence. That is why subjectivation in suicide can be allowed, in spite of its great expense. For, even if the act of suicide leads to the first death, this act in its process, by revealing the second death most prominently, 
releases the enormous power of life as one with the force of the Outside, in order to create these new modes of existence.

Even though the act of suicide can become such subjectivation in its process, it seems to close its openness to the Outside in its result, insofar as it ends up with the first death which fixes the identity of a dying person and fills the fracture of the self. However, this is not the case with Deleuze, because of the singularity of the personage who kills himself. When a philosopher of life, an advocate of the affirmation of life commits suicide and terminates his life, a gap yawns between his thoughts on life and his chosen death. Through this gap's destruction of his identity, he is prevented from being confined in it, and opens another gap which appears in the process of suicide, the second death, allowing it to emerge from the doom of its reduction to the first death. At this point, the first death turns against itself and meets the second death. The resulting fracture of identity not only prevents the fracture of the self in the process from being filled, but also undermines the base for the restitution of the subject and its guarantor. The act of killing oneself coincides with the act of killing the subject, along with its guarantor.

Such a self-destructive act undertaken by a philosopher of life is therefore an act of killing himself as the father. By removing himself as the progenitor, this act invites his sympathizers to liberate themselves from the docile acceptance of his thought, and to pursue their own paths of thought, each of which is different, even from his. He means to liberate his thought itself. For, if the affirmation of life must be the affirmation of multiplicities, then, in order for it to go to its limit, any unifying principle must be thrown away, including the precursor and progenitor of this affirmation. Emptying himself thus is equivalent to resisting the authorization of himself and the dogmatization of his thought. In other words, by giving himself death he is giving others, and his thought, life. It is the last thing that he could do for his thought. It is an act of 'once and for all', for 'every time' from now onward, towards the affirmation of life as multiplicities. Among the images of 
acts which symbolize the pure form of time, Deleuze puts "to kill God or the father" beside "to throw oneself into the volcano" ${ }^{42}$. As the combination of these images hints, his act of suicide in Empedocles' manner is also the act of killing not only the Father but also the father as himself.

When the act of suicide thus destroys the identity of the subject, along with the unity of its guarantor, it keeps the process of subjectivation open beyond its result. Breaking through the confinement within personal identity, death becomes endless and continues to trace the plane of immanence, resisting the plane of transcendence. This infinite movement is the gift of Deleuze's death. It is the call for beings to come which can live with the power expressed in suicide without committing it, in hope that we do not die as he did, but live otherwise, differently.

${ }^{1}$ Gilles Deleuze, The Logic of Sense, trans. Mark Lester with Charles Stivale (New York: Columbia University Press, 1990), p. 128. Logique du sens (Paris: Minuit, 1969), p. 153. 2 A. de G., Le geste d'un philosophe. Libération, (6 novembre 1995), p. 8. Yannick Beaubatie also takes Deleuze's suicide as such an aphorism and anecdote. Grandeur de Gilles Deleuze. Tombeau de Gilles Deleuze (Tulle: Mille Sources, 2000), 9-20, p. 16.

${ }^{3}$ Deleuze, The Logic of Sense, "Eighteen Series of the three Images of Philosophers". Logique du sens, "18e série des trois images de philosophes".

${ }^{4}$ Andre Pierre Colombat, November 4, 1995: Deleuze's Death as an Event. Man and World: An International Philosophical Review 29 (1996), 235-49, p. 245.

5 Ibid.

${ }^{6}$ Maurice Blanchot / Jacques Derrida, The Instant of My Death / Demeure, trans Elizabeth Rottenberg (Stanford: Stanford University Press, 2000), p. 101. Derrida, Demeure (Paris: Galilée, 1998), p. 138.

${ }^{7}$ Maurice Blanchot, The Writing of the Disaster, trans. Ann Smock (Lincoln and London: University of Nebraska Press, 1995), p. 69. L'Écriture du désastre (Paris: Gallimard, 1980), p. 113.

8 Mauricd Blanchot, The Space of Literature, trans. Ann Smock (Lincoln and London: University of Nebraska Press, 1982), p. 125. L'Espace littéraire, (Paris: Gallimard, 1955), p. 126.

9 Blanchot, The Writing of the Disaster, p. 41. L'Écriture du désastre, p. 70.

10 Immanuel Kant, Critique of Pure Reason, trans. Norman Kemp Smith (London: MacMillan and Co., 1929), B157-158, p. 169n, Kritik der reinen Vernunft, Kant's gesammelte Schriften III (Berlin: Academie, 1904), p. 123n,; italics in text.

11 Thomas Carl Wall discusses on "passivity in the radical sense, before it is simply 
opposed to activity" that is, the passivity which "is passive with regard to itself, and thus it submits to itself as though it were an exterior power" in his Radical Passivity: Levinas, Blanchot and Agamben (New York: State University of New York Press, 1999), p. 1. 12 Blanchot, The Writing of the Disaster, p. 69. Translation slightly altered. L'Écriture du désastre, p. 113.

13 Blanchot, The Space of Literature, p. 104. L'Espace littéraire, p. 105.

14 Blanchot, The Writing of the Disaster, p. 69. L'Écriture du désastre, p. 113.

15 Gilles Deleuze, Difference and Repetition, trans. Paul Patton (London: The Athlone Press, 1994), p. 259. Différence et Répétition (Paris: P. U. F., 1968), p. 333.

16 Deleuze, The Logic of Sense, p. 156. Translation slightly altered. Logique du sens, pp. 182-183.

17 Ibid, p. 161. p. 188.

18 Ibid, p. 157. Translation slightly altered. p. 184. I have changed 'she' to 'he', taking "the abstract thinker" as a pointed description of Blanchot.

19 Ibid, p. 157. p. 183.

${ }^{20}$ Ibid, p. 152. p. 178.

${ }^{21}$ Ibid, pp. 149-153. pp. 175-179.

22 Deleuze, Difference and Repetition, p. 89. Différence et Répétition, p. 120.

${ }^{23}$ Deleuze, The Logic of Sense, p. 156. Translation slightly altered. Logique du sens, p. 182. ${ }^{24}$ Blanchot, The Writing of the Disaster, p. 68. Translation slightly altered. L'Écriture du désastre, pp. 111-112.

${ }^{25}$ Blanchot's critique of Hegel is associated with his reading of Nietzsche's discussion of the death of God, against Hegelian dialectics. In contrast, Altizer regards Nietzsche as a successor to Hegelian dialectics, and finds in the death of God or the crucifixion of Christ, the resurrection of Christ and the realization of Absolute Spirit. Thomas J. J. Altizer, The Contemporary Jesus (London: SCM Press, 1998), p. 186. For Altizer, Nietzsche's formulation 'Dionysus-Crucified' signifies the unity of the Overman who overcomes the human and Christ who dies for this overcoming, implying the assimilation of Nietzsche in madness with Christ. Ibid, pp. 153-159. Protesting against Hegelian dialectics, Deleuze also sees in this formulation "the synthesis of Dionysus and Christ". Gilles Deleuze, Nietzsche in Pure Immanence: Essays on A Life, trans. Anne Boyman (New York: Zone Books, 2001), p. 96. Nietzsche (Paris: P. U. F., 1965), p. 45. But here, the death of Christ, equated with the birth of Antichrist as the Overman, means, far from the realization of Absolute Spirit, the destruction of such totalizing principle. Along this line, the suicide of Deleuze himself, overlapped on Nietzsche's madness, can be understood as a kenotic death in such a sense. I simply sketch an outline of such a possible argument.

${ }^{26}$ Deleuze, Difference and Repetition, p. 95. Différence et Répétition, p. 127; italics in text. 27 Ibid.

28 In Difference and Repetition, Deleuze finds in the basis of the fracture of the self fundamental passivity which appropriates the activity exceeding that of the human subject. He regards this passivity as neither "I think" nor "I am" but rather another subject from which they both emerge. I outlined this idea in my Death and Revival of the Subject in Deleuze's Philosophy (Japanese). The Philosophy (Tetsugaku): The Annual Review of the Philosophical Association of Japan (1998), 280-289, pp. 287-288. Although this concept of another subject is not a noticeable part in his works, it is continued in his later concept of subjectivation which he borrows from Foucault. I will mention the latter concept in this essay. 
${ }^{29}$ Deleuze, Difference and Repetition, p. 89. Translation slightly altered. Différence et Répétition, p. 120; my italics.

30 Ibid, p. 95. p. 127.

31 Maurice Blanchot, The Work of Fire, trans. Charlotte Mandell (Stanford: Stanford University Press, 1995), pp. 291-292. La part du feu (Paris: Gallimard, 1949), p. 282.

32 Ibid, p. 292. p. 283. Translation slightly altered.

33 Ibid, p. 296. p. 287. Translation slightly altered.

34 The death of God for Blanchot can be understood in the context of the relationship of his notion of the neutral and Rosenzweig and Levinas' thoughts. Rosenzweig claims that I become myself by kneeling before God as the absolute Other. Levinas calls His Otherness illeity, distinguished from il $y$ a of the impersonal being of beings. Blanchot confuses these two terms into his notion of the neutral. Based on such ambiguity, which blurs the borderline between God's existence and absence, he conceives the death of God as the event with neither beginning nor end.

35 Deleuze, Difference and Repetition, p. 91. Différence et Répétition, p. 122.

36 Gilles Deleuze and Félix Guattari, What Is Philosophy?, trans. Hugh Tomlinson and Graham Burchill, (London and New York: Verso, 1994), p. 45. Qu'est-ce que la philosophie? (Paris: Minuit, 1991), p. 47.

37 While Badiou insists that, in Deleuze's thought, the supplement of the virtual ruins the reality of the actual, Žižek insists that the supplement of the virtual constitutes the reality of the actual. Cf. Alain Badiou, Deleuze: La clameur de l'Etre (Paris: Hachette, 1997), p. 69. Slavoj Žižek, Organs without Bodies: Deleuze and Consequences (New York and London: Routledge, 2004), p. 84. But, in effect, whether the virtual or the actual has priority does not matter, because what is important in Deleuze is the interaction between them, coupled in their genuine difference. Whereas anything actual comes from the Outside, as a part of its infinite movement, the subsistence of this virtual is confirmed only by its ceaseless actualization. It is in the same way that the plane of immanence, as the field of the virtual, is presupposed by the thought of each philosopher, but nevertheless must be instituted by his or her act of thought. See, Deleuze and Guattari, What Is Philosophy?, pp. 40-41. Qu'est-ce que la philosophie?, pp. 43-44.

38 Deleuze, Difference and Repetition, p. 95. p. 127.

39 Ibid.

40 Gilles Deleuze, Negotiations (New York: Columbia University Press, 1995), p. 114.

Translation slightly altered. Pourparles (Paris: Minuit, 1990) p. 154.

${ }^{41}$ Deleuze, Difference and Repetition, p. 89. Différence et Répétition, p. 121.

42 Ibid. p. 89. p. 120. 